\title{
The Civil War in the American Ruling Class
}

\author{
Scott Timcke
}

\author{
Department of Literary, Cultural and Communication Studies, The University of The \\ West Indies, St. Augustine, Trinidad and Tobago, Scott.Timcke@sta.uwi.edu
}

\begin{abstract}
American politics is at a decisive historical conjuncture, one that resembles Gramsci's description of a Caesarian response to an organic crisis. The courts, as a lagging indicator, reveal this longstanding catastrophic equilibrium. Following an examination of class struggle 'from above', in this paper I trace how digital media instruments are used by different factions within the capitalist ruling class to capture and maintain the commanding heights of the American social structure. Using this hegemony, I argue that one can see the prospect of American Caesarism being institutionally entrenched via judicial appointments at the Supreme Court of the United States and other circuit courts.
\end{abstract}

Keywords: Gramsci, Caesarism, ruling class, United States, hegemony

Acknowledgement: Thanks are due to Rick Gruneau, Mariana Jarkova, Dylan Kerrigan, and Mark Smith for comments on an earlier draft. Thanks also go to the anonymous reviewers the work has greatly improved because of their contributions. A version of this article was presented at the Local Entanglements of Global Inequalities conference, held at The University of The West Indies, St. Augustine in April 2018.

\section{Introduction}

American politics is at a decisive historical juncture. Stalwarts in both the Democratic and the Republican Parties foresee the end of both parties. "I'm worried that I will be the last Republican president", George W. Bush said as he recoiled at the actions of the Trump Administration (quoted in Baker 2017). When reflecting on the significance of his speakership, John Boehner believes it marks "the end of the two-party system" (quoted in Alberta 2017). In the Democratic Party Bernie Sanders (2012) wants to "wage a moral and political war against the billionaires", while Nancy Pelosi forcefully declares "we're capitalists, that's just the way it is" (quoted in Raskin 2017). Reading not only with an eye to "incurable structural contradictions" (Gramsci 1971, 178), these statements can be juxtaposed with the conspicuous absence of genuine substantive discussion about Jeb Bush and Hillary Clinton being the frontrunners in the two-year lead up to the 2016 election. Not only is this significant given that members of their families have held presidential office, but also because the funds required to run a presidential campaign appear to demarcate electoral politics as the sole domain of select dynasties competing against one another, which competition in turn requires great personalities at the helm of these campaigns. ${ }^{1}$

It should be no surprise that these observations and testimonies emerge at the crest of massive capital consolidation, where class warfare 'from above' has created intense social inequality which has stratified the American social structure, a revanche

\footnotetext{
${ }^{1}$ For example, the 2016 US electoral cycle cost $\$ 6.5$ billion, with the $0.01 \%$ contributing $\$ 2.3$ billion (see Sultan 2017).
} 
in the wake of the 2008 recession. The prospect of a 'winner-takes-all' economy has created conditions for the outbreak of a low-intensity civil war in the American ruling class. By this I mean an internal Gramscian 'war of position' as factions are slowly, but viciously, competing to attain or retain command of the political economy of the United States; these factions are testing and trying to restore or reconstruct a world that better caters to their particular capital accumulation strategies, seeking to gain hegemony. Again: this 'slow violence' of intra-class struggle should not be surprising. As Marx outlined, capitalists must accumulate or be accumulated.

Still, with President Donald Trump, the aforementioned conjuncture resembles Gramsci's description of a Caesarian response to an "organic crisis", a protracted event which comes about when "the forces in conflict balance each other in a catastrophic manner", leaving space for a third party to intervene (Gramsci 1971, 219). In this war of position, Trump's efforts to discredit segments of the media to confine their attention to channels that are conducive to his politics are indicative of factions of the ruling class's authoritarian tendencies. But Trump's erratic behaviour must not derail attention to the formation of - and competition between - different capitalist social blocs. Much like Marx's rebuke of Hugo's "bolt from the blue", we cannot see these tendencies as the "violent act[s] of a single individual" (Marx 2006/1986). And so, we have an interregnum with all the encumbered morbid symptoms.

\section{A Methodology to Study an Organic Crisis}

Influenced by Gramscian analytical categories, in this article I argue that catastrophic equilibrium has created an organic crisis in the US, thus permitting Caesarism to arise. This crisis involves a struggle for hegemony under conditions of extreme social inequality, and moreover one can identify that media systems are a key element in the civil war, both as a site of struggle and as an instrument of that struggle. ${ }^{2}$ Keeping these precepts in mind, in the coming sections, I examine several interlinked events to trace some of the front lines in the civil war. These case studies involve efforts to stave off class struggle 'from below' (Section 4), discussions of how Silicon Valley's 'information robber barons' use their platform to forge an infrastructure for reactionary populism (Sections 5 and 6), and the attempts to capture the judiciary, thereby ensuring a 'passive revolution' (Section 7).

Admittedly, this is a big argument, one with many moving components and pieces of evidence that require marshalling. If this seems something of an unwieldy intellectual framework, I wish to echo Christian Fuchs' sentiment when he writes of ideology: "of course this is complex, it is necessarily complex" (Fuchs and Winseck 2011, 256). For

2 I am sympathetic to Nick Couldry and Andreas Hepp's (2016) emphasis on a media-centred approach to communication research. In distinction to media-centric approaches (where the media is a driver of change), a media-centred approach proposes that the media is a key venue where social changes can best be identified (see Hepp, Hjarvard and Lundby 2015). For Couldry and Hepp, this analysis of place arises because of the 'deep mediatization' of organisational and social life writ large. As deep mediatisation affects conceptions of epistemology, ontology and personhood, the explanatory utility of a media-centred approach is that it points to a new political economy of reality. For myself, this requires researchers to ask which classes can disproportionately shape this reality, how they use the media as instruments to this great end, and what might the consequences be for prospects of collective social life. 
this reason I purposefully situate the article within the developing literature attuned to class struggle in media studies (see Fuchs 2009; Nixon 2017). ${ }^{3}$

While I remain circumspect about the absolute autonomy of the political realm (cf. Briziarelli and Guillem 2016, 18-36) a rich vein of recent international scholarship indicates a revival of Gramsci's social and political thought through application to the current global political conjuncture (ex. McNally and Schwarzmantel 2009, although Thomas's (2009) magisterial The Gramscian Moment stands out as the preeminent intellectual endeavour on this front). Attention to Gramsci's thought was readily useful when delineating the mechanics of regimes of knowledge in the age of mass representative politics provided clear means to see the "complex contradictions and interconnections between capitalist social relations, civil society, political society and the state apparatus" (Humphrys 2018, 29-30). I believe that Gramsci has similar utility in an age of "deep mediatization" (Couldry and Hepp 2016; see footnote 2 in this article) where these 'complex contradictions and interconnections' are extended by digital means, which have concurrently made new manoeuvres possible. Accordingly, Gramsci's categories offer an approach that considers the various social properties of actors and the social forces engaged in the production, circulation and authorisation of knowledge, one that can be usefully taken up to analyse digital media systems in the US in the first part of the 21st century. Although it is not my purpose here to discuss the concept at length there is some value in keeping it in mind as this article unfolds.

Gramsci's conception of an integral state involves consent and coercion that interrelate, thus allowing the capitalist state to defend capitalist social relations. Peter Thomas $(2009,189)$ provides a tidy summary of the integral state as "the image of 'political society' as a 'container' of civil society, surrounding or enmeshing and fundamentally reshaping it". This conceptualisation offers an expanded understanding of how capitalist societies reproduce, which Gramsci notes is a "complex of practical and theoretical activities with which the ruling class not only justifies and maintains its dominance, but manages to win the active consent of those over whom it rules" (1971, 244). The "dialectical unity" that Humphrys $(2018,37)$ describes allows researchers to see how civil society and the state are but "different sites of social practice: civil society is the location of hegemonic practice and political society is the site of direct domination". By the term "organic crisis", Gramsci described a conjecture where

A crisis occurs, sometimes lasting for decades. This exceptional duration means that incurable structural contradictions have revealed themselves (reached maturity) and that, despite this, the political forces which are struggling to

\footnotetext{
${ }^{3}$ Although it is not my chief concern in this article there is a point about hegemony worth noting. Geoff Mann (2016) insists that the point of the labour theory of value is to identify how value functions to reproduce capital's hegemony. The "paradigmatic instrument of hegemony" he writes, "value is the means by which the particular interests of the hegemonic historic bloc (capital) are generalized, so they become understood as the general interest". While Gramsci is readily associated with this point, Marx and Engels $(1970,54)$ discussed the point in The German Ideology: "every class which is struggling for mastery, even when its domination, as is the case with the proletariat, postulates the abolition of the old form of society in its entirety and of domination itself, must first conquer for itself political power in order to represent its interest in turn as the general interest, which in the first moment it is forced to do".
} 
conserve and defend the existing structure itself are making every effort to cure them, within certain limits, and to overcome them $(1971,178)$.

By "war of position", Gramsci conceived the concept as "the whole organizational and industrial system of the territory which lies to the back of the army in the field" (1971, 234). I interpret this to mean the organisational infrastructure that supports political field operations seeking to constitute the political ideologies that take hold in popular culture. The value of this approach is that some factionalism in the ruling class is to be expected simply because they are also competitive market actors undertaking capital accumulation strategies. Still, in moments of an organic crisis, these factions ramp up their contests, to a degree that I suggest could be considered a low-intensity civil war.

Michael Lind (2017) is of similar mind regarding an infrastructure for class warfare "from above". ${ }^{4} \mathrm{He}$ writes that "a transatlantic class war has broken out simultaneously in many countries between elites based in the corporate, financial, and professional sectors and working-class populists". Still, he dismisses Marxian analysis as "deluded" because of "its secularized, providential theory of history and its view of industrial workers as the cosmopolitan agents of global revolution". Instead he opts for a theory of elite conflict to explain the current conjuncture. By contrast, I am not convinced that Gramsci's Marxism is stale, especially when it comes to class analysis in the wake of the 2008 recession. The reasons for this view will become apparent as this article progresses. As such, I strike out in a different direction than orthodox 'elite studies' (cf. Hoffmann-Lange 2007; Semenova 2018). I do so because, as Amelia Arsenault and Manuel Castells (2008) note, "the ability to control connection points between different networks (e.g. business, media and economic networks) is a critical source of power in contemporary society". Their view is reminiscent of, although not congruent with, Gramsci's analysis of hegemony, which proposes that cultural practices and institutions generate and induce consent of subordinate classes; in other words, the ways in which a class or faction comes to gain power to lead a social structure and how this power is expanded then reproduced. The advantage of an analysis that begins with hegemony is that it is sensitive to class warfare directed both downwards and laterally, in turn attentive to the formation of alliances and other kinds of pacts.

${ }^{4}$ There are several reasons for using Michael Lind as a narrative and counter-explanatory foil, most of which involve his central place in American politics. Lind began his career as a political appointee in George Bush's state department during the Gulf War. During Bill Clinton's Administration, Lind became the editor of The National Interest while writing for Harper's, The New Republic and The New Yorker. Throughout his career he has been an extremely influential neo-conservative gatekeeper, operative, and man of letters. Granted, I could review the neo-conservative thought of Richard Haas, Robert Kaplan, or John Bolton - who has overcome banishment and returned to the White House - but Lind deserves unique consideration because of his role in founding the New America Foundation, arguably the most important think tank in the US at the moment. (Awash with Google money, New America is where many progressive-neoliberal Obamacrats like Anna-Marie Slaughter have been employed.) There is a second consideration: as far as I can discern, Lind has not had a Damascus experience and become a Democrat; rather his role in the New America Foundation illustrates the rightward drift in the Democratic Party over the past few decades, the kind of observation that has caused Adolph Reed, Cornell West and other black radical American scholars to be shunned and sidelined from Democratic Party circles. Altogether, these two points mean that we can use Lind's social and political thought as an admittedly rough and incomplete barometer for insider US policy concerns about social inequality, i.e. the ideology of actually-existing capitalism, as opposed to critical empirical assessments of the consequences of capitalist social relations, a task I seek to undertake in this article. 
As the ruling class's influence traverses all aspects of American society, the consequences of the civil war can be seen in most places. Nevertheless, for brevity I focus on cases that involve digital media. I trace how these instruments are pitted against one another by capitalists to gain influence over the commanding heights of the American social structure. When doing so, I try to avoid a reductive treatment of power as an abstract category. Rather, to the extent that one can, given constraints of form and publicly available evidence, I look at the actions of historical situated members of the ruling class. As such, these cases correspond to elements within Gramscian hegemony - how factions gain, consolidate, and then reproduce power. But before getting to these sections, I briefly review Lind's argument about the nature of contemporary class warfare to show that it misjudges the primary lines of division. This critique paves the way for an analysis predicated upon wars of position which have led to Caesarism.

\section{The Limits of Lind's New Class War}

Despite the merit of Gramscian analysis, class differentiation and subordination tends to be downplayed in self-proclaimed 'democracies' like the United States. This is partly because, in this polity, nominally formal authority is decided by contests between political parties themselves comprised of legally free and equal citizens undertaking voluntary actions. This nominal status allows legal equality to eclipse and circumvent discussions detailing how social inequalities aid the various machinations of the ruling class. To some extent, Lind echoes this view. He writes that

None of the dominant political ideologies of the West can explain the new class war, because all of them pretend that persisting social classes no longer exist in the West. Neoliberalism - the hegemonic ideology of the transatlantic elite pretends that class has disappeared in societies that are purely meritocratic, with the exception of barriers to individual upward mobility that still exist because of racism, misogyny, and homophobia. Unable to acknowledge the existence of social class, much less to candidly discuss class conflicts, neoliberals can only attribute populism to bigotry or irrationality (Lind 2017).

Still, in Lind's account of the civil war in and among classes, the "managerial elite" is the key agent of domination. These managers are "private and public bureaucrats who run large national and global corporations" (Lind 2017). Comprising about $10 \%$ to $15 \%$ of the US population as measured by advanced higher education, Lind proposes these managers are prone to "Orwellian groupthink" which can have negative consequences given that they "exercise disproportionate influence in politics and society" (2017). Finally, these managers may be "independently wealthy, but most are salaried employees or fee-earning professionals. Most of today's billionaires were born into this upper-middle class" (Lind 2017). As such, this class provides the base for highachieving members to attain control of the commanding heights of American society.

Following this identification and demarcation, Lind's account of class war begins with the post-1945 social pact between technocratic managers and national labour, an apparent concession to safeguard against communism. The outcome of this pact was a "golden age of capitalism from the 1940s to the 1970s, combining high growth with a more equal distribution of its rewards than has ever existed before or since" (Lind 2017). However, along with social protections, workers' bargaining power was eroded after the Cold War as ideological threat receded. Opportunistically, managers used their dominant positions to enrich themselves, hoarding wealth at labour's expense. 
The techniques for appropriation included the use of multi-national corporations to coordinate mergers and corporate consolidation, the creation of transnational supply chains, favourable trade treaties, and increased use of tax havens. Because of these accumulation strategies, "large elements of the native working classes in Western democracies have turned to charismatic tribunes of anti-system populism in electoral rebellions against the selfishness and arrogance of managerial elites" (Lind 2017). Moreover, "suppressing wages and thus throttling mass consumption," Lind suspects, will likely limit growth, in turn causing the onset of "a kind of high-tech rentier feudalism" (2017). The by-product of this, Lind proposes, may be a destructive politics that oscillates between oligarchs and populists.

There is some merit to Lind's identification of the American ruling class: the top $20 \%$ do own near $90 \%$ of all privately held asserts (Wolff 2017). And I generally agree with his reading of history. However, when one examines other discrete categories, this criterion for membership becomes difficult to sustain: just because managers do the bidding of capitalists, they no more share the same class than do workers who do the bidding of capitalists. Moreover, there are quantitative and qualitative differences in wealth distribution between the $1 \%$ and their agents. The threshold for household membership to the $1 \%$ is a net worth near $\$ 4$ million (Saez and Zucman 2014). Together, this group owns roughly $36 \%$ of all private wealth. For financial wealth, their share is over $40 \%$. For stock, the share increases to $50 \%$; for business equity, over $60 \%$ (Wolff 2014). But even within this cluster, there are significant differences between the $0.01 \%$ and the remaining $1 \%$. The wealth threshold in order to be categorised as a member of the $0.01 \%$ is $\$ 111$ million. The 6,000 -odd families that belong to this group average a net worth of $\$ 371$ million (Saez and Zucman 2014). Worth noting is that Trump's cabinet has more wealth than the bottom third of Americans combined.

When examined at this level of granularity, the central problem of Lind's argument is that it permits the broad distribution of blame. But, not identifying capitalists directly as such, Lind's argument inadvertently deflects and diffuses acute criticism of the economic regime by including their principle agents and other professionals. One implication of this line of reasoning is that the top $20 \%$ have to admit disproportionate complicity to shield their employers. In effect, they must do this additional emotional labour of confessing harm to earn their loyalty rents. By contrast, a narrower view can identify the factions within the ruling class to see the socially devastating ramifications of their various accumulation strategies. It is worth remembering that the ruling class is not a monolithic entity - different factions may advance different practices and visions of capitalism - even while its intervention into social life is omnipresent, if uneven. So it remains important to attend to divergences between factions, which provide space for movement that activists, organisers, and advocates can exploit. Efforts of this sort will be important given the present 'catastrophic equilibrium' in the United States. To this end, the following sections examine cases where different capitalists pursue different strategies, form different alliances, and viciously compete against one another. I shall begin with Hillary Clinton's progressive neo-liberalism.

\section{Staving Off Class Struggle 'From Below'}

In reflecting upon "the indispensability of continued American leadership in service of a just and liberal order", and "America's bipartisan commitment to protecting and expanding a community of nations devoted to freedom, market economies and cooperation", Hillary Clinton (2014) believes there is "really no viable alternative". Reminiscent of George W. Bush's remarks in the National Security Strategy, what she 
means is that there is no other social structure suitably amenable for a capitalist ruling class: no other option but uneven development and dispossession will be permitted. Conditional concessions will likely occur, yes, but not at the expense of perpetuating profit.

The 2016 Democratic Primary provides a good recent example of the tolerable limits for alternatives. Consider that initial predictions gave Bernie Sanders no more than two state victories. Yet, by raising over $\$ 228$ million with nearly $60 \%$ coming from small donations of less than $\$ 200$ (Open Secrets 2018b), he more than exceeded those expectations. Come the Democratic Convention, Sanders had received around $43 \%$ of the total vote and won 23 states with several others virtual ties or near misses. These wins came despite Hillary Clinton's having every structural advantage that America's foremost political dynasty could offer, and some allegations - although little evidence - of vote-tampering through state-level procedural discretion. What should have been an easy path to victory for the ruling class was nearly upset by Sanders' articulation of the connection between social inequality and capitalism, an effective message because most Americans' lived experience features no recovery, but instead is characterised by pauperisation and class decomposition. Working within the confines of American electoral politics, where form drives substance, Sanders followed a simple but effective strategy of making excessively reasonable moral demands that reform would not provide, thus showing the limitations of the present social structure.

Faced with a genuine threat, Hillary Clinton's campaign trivialised Sanders, and in a move reminiscent of neo-conservatives shielding their unreasonable support of Israel by accusing critics of anti-Semitism, the campaign framed Sanders as sexist. Within this narrative, Sanders' refusal to concede early was thwarting female political aspirations. However, this neglects Sanders' efforts to consolidate the advantage he had acquired in the party to advance his goals to contest the soul of Democratic Party, especially on down ballot races with candidates who were his supporters, many of whom were women. Indeed, young women disproportionately lent their support to Sanders (Rappeport 2016), not only because his policies were arguably more favourable for women, but also because the dividends of class politics offered the best prospects for material improvements in their lives. Put simply, Sanders offered to complement representation with redistribution and recognition. For some on the radical left - the left informed by labour and political economy - the rally behind Sanders was a plausible path to wielding some sort of meaningful power. It would not have ended capitalist accumulation, but even temporary alleviation could have had a significant impact on the quality of people's lives.

In a related manoeuvre, it was repeated that Sander's success should not be celebrated because it was driven by 'Bernie Bros', a group of disaffected men whose sought to halt a female presidency. For example, when Sanders complained about electoral violations in the Democratic primary, Joan Walsh (2016) said he ought to change his behaviour lest he become "the messiah of an angry, heavily white, and male cult". She then asserts that Sander's coalition was "dominated by white men, trying to overturn the will of black, brown, and female voters or somehow deem it fraudulent". This kind of framing was so common that in his post-primary review of Sander's campaign, Adolph Reed noted how the trope of "'brocialist' men who threatened feminists with rape or other violence for their reluctance to subordinate feminist concerns to a male-centered class-reductionist socialism" (see Reed and Zamora 2016) became one tactic to try circumvent Sander's popular support.

Seizing on remarks by Robinson Meyer (2015; 2016), the trope emerged from a seeded public relations campaign which suggested that these men were undertaking 
an organised campaign to bully and intimidate Hillary Clinton's supporters. Of course, cyber-bullying, criminal harassment, everyday sexism and digital rape culture are online problems. Certainly, this does much harm to women and many others (ex. Hess 2014). All of this is true. Nevertheless, citing the lack of evidence of sexism's being an inherent and condoned feature of Sander's campaign - and considering how this rhetoric erases millions of Sander's female supporters - Glenn Greenwald's (2016) investigation of the public relations eco-system concluded that this "cheap campaign tactic" was perpetuated by a willing and compliant media.

This is not to say there were no Sanders supporters who were toxic and said awful things in his name (see Albrecht 2017; Wilz 2016), but rather to suggest that the amorphous term 'Bernie Bros' came to encompass both real and imagined abuses. However, at the same time, the term was used to suggest an intensity and scope of harassment constituting a core feature of Sander's campaign operations, but this did not reflect reality. For example, a year after the Democratic primary, notable Clinton surrogate Jill Filipovic (2017) admits that this toxicity was not Sanders' fault, but she maintains that his "attacks on the Democratic Party helped set the stage for this thoroughly dysfunctional, and ultimately destructive discourse". This statement reveals the kinds of politics at play. To be clear, much like Reagan's "welfare queens" (quoted in The New York Times 1976) or the ways in which contemporary conservative discourses on immigration use the part to stand for the whole, there are manufactured mythical figures in US politics that inflate real experiences until they become ideology writ large. And so the point here is to ask what work the term does for political aims, and how rhetoric is marshalled in the public sphere to negate alternative political programs before they gain traction.

Granted, smears are common in American politics, but Hillary Clinton's were in a separate category because a campaign staff numbering more than 700 personnel (see Vogel and Arnsdorf 2016) for basic details of organisation infrastructure), nearly unlimited funds, and an untold number of employees in allied Super PACs (political action committees). In 2016 alone, Priorities USA Action raised and spent close to $\$ 192$ million, with \$127 million targeting Republicans (Open Secrets 2018c). In the case of Correct the Record (2016) they allocate funds to "to push back against attackers on social media platforms like Twitter, Facebook, Reddit, and Instagram". They write:

Lessons learned from online engagement with "Bernie Bros" during the Democratic Primary will be applied to the rest of the primary season and general election-responding quickly and forcefully to negative attacks and false narratives. (Correct the Record 2016)

"False narratives" here equate to inconvenient facts like Hillary Clinton's support for the Iraq war, however much hedges about procedural platitudes are retroactively introduced.

An 'appropriate narrative' can be seen in a major interview-based profile by Traister (2016) in New York Magazine. The piece does not mention Hillary Clinton's vote to support the Iraq War, nor her involvement in welfare reform. Notwithstanding the constraints of journalistic conventions, Traister nevertheless does relay Hillary Clinton's thoughts on yoga, television and popular culture. This humanisation precedes a tame list of several orthodox Democratic domestic policies that are meant to indicate Hillary Clinton's pragmatic stamina for boardroom politics while positioning critiques as having to resort to sexist political hounding because all other avenues of rebuke are 
insubstantial. The point here is not to castigate Traister. Nor is it to deny that Hillary Clinton has faced entrenched categorical inequality because of her gender. But it does illustrate how selective media access can incentivise pliability. Similar narrative management is evident in the paperback version of Hard Choices, Hillary Clinton's memoir. Released in time for the campaign, about 100 pages are abridged, conveniently skirting difficult topics like her role in the coup in Honduras (see Beeton and Tang 2016).

Returning to Correct the Record, the phrase "The task force currently combats online political harassment" is revealing for how it construes dissent and contention using empirical facts as sexist. Involved in this reconfiguration is deliberate malleability of the term 'harassment'. What I mean is that there is a strategic misuse of the term when deployed in online political and social discourse to stall and silence due criticism. In this respect, there is cause to re-evaluate how stigmatising disagreement and appeals to civility allow the ruling class to introduce mechanisms to limit dissent, whether through technical interventions, legal frameworks, or cultural norms. All of this aims to limit unwanted participation in politics, thereby ensuring that 'the party still decides' (ex. Cohen et al. 2008). Indeed, in the Citizen's United era the Democratic Party's strategy was to 'purchase' an electorate by marshalling audience power through an unrelenting barrage of political broadcast ads tuned by the best campaign intelligence and data analysis.

The embrace and justification of Super PACs is demonstrative of drift in the Democratic Party. Where once it was a tenet in the party that corporate money corrupts politics, Hillary Clinton and her supporters deny this. Instead, they subscribe to the Scalia-Roberts line of reasoning in Citizen's United Ruling that money is not inherently corrupting. (There is an aura of melancholy about this, as Citizen's United used Hillary: The Movie, a slanderous propaganda film, as the vehicle for their Supreme Court case.) Democrats, in efforts to defend Hillary Clinton, have occupied positions they once so strongly advocated against.

This drift reveals a contradiction in the Democratic Primary process: the usage of intersectionality selectively ignores class and fails to undertake a power analysis, let alone raising Hillary Clinton's participation in the execution of unlawful wars. In being solely preoccupied with gender representation, this vulgar intersectionality overlooks a basic feminist observation that women, as much as men, can reproduce and uphold a racist, patriarchal variety of capitalism. Indeed, given the broader class protest carrying Sander's long run, Hillary Clinton's support of free trade and opposition to a $\$ 15$ minimum wage is indicative of her affiliation with the ruling class' interests and thus the need to obfuscate her policy positions. It is for this reason that the campaign focused so much on civility and decorum, because staffers knew that their policy case was weak. Another disconcerting element in this politics was that Clinton had a reservoir of support in the older black population (Stockman 2016), while nevertheless being a key member of an administration that further entrenched governance through criminalisation that decimated young poor black men and women. In sum, the campaign adopted the language of intersectionality, but not the practice.

In repressing class politics 'from below', it is important to register what conception of identity was mobilised for political purposes. Consider how Hillary Clinton's rhetoric was predicated upon slogans and hashtags like 'I'm with Her'. The inference is that Clinton's election could be a symbolic victory over the underrepresentation of women in politics; but also a substantial one because she is a highly accomplished and extremely capable public servant. Yet despite her lengthy qualifications, a good portion of her support is begrudging, and this was particularly acute among women under the 
age of 35. That Hillary Clinton is not seen in a favourable light is often attributed to everyday sexism, but this 'enthusiasm gap' argument becomes more difficult to sustain when attempting to account for the lack of support from younger women. In this case the gap is attributed to women's inexperience in politics. Explicitly directed at young women, Madeleine Albright remarked at a Hillary Clinton campaign rally that "There's a special place in hell for women who don't help each other", while the day before Gloria Steinem attributed young female support for Bernie Sanders to infatuation with men. "When you're young, you're thinking: 'Where are the boys?" Steinem said. "The boys are with Bernie" (quoted in Rappeport 2016). Notwithstanding the presumption that Hillary Clinton has a right to support from this segment of voters, the 'enthusiasm gap' amongst already-committed Clinton supporters is informed by knowledge of her hawkish foreign policy positions and incarceration of the truly disadvantaged. The electorate is wary of reproducing systems of violence, but have few other genuine options in a rigid social structure where there is 'really no viable alternative'.

The aforementioned foreclosure points to a contradiction in Clintonian politics: the obsession with narrow white neoliberal ruling-class feminism closes categories required to partake in politics, effectively forestalling the kinds of interactions required to create alternative social structures wherein oppression based upon subjective social categories is not as prevalent nor as damaging. While one can be critical of identity politics, this does not imply that whiteness is the natural centre of study, nor that a decentring cannot have positive effects. Therefore, it is valuable to assess if the dismissal of identity politics is a pre-emptive effort to keep whiteness as the standard for political appraisal. That said, the intended practice of intersectional analysis is to identify the links between oppressions. Positioning them against one another, as done by Hillary Clinton's staff and surrogates, aims to divide and rule, revealing a calculation to shield the powerful from criticism by the powerless. The heralding of this kind of calculated politics and manipulation to divide populations by exploiting social problems emanating from the very same social structure that American electoral politics seeks to safeguard and preserve is foreboding. Indeed, it does little to aid introspection into these very politics.

Following Clinton's loss in the 2016 election, the Democratic Party began (and continues) a long, conflict-ridden process to analyse its platform and regroup its strategy. Involved in this process was the publication of Donna Brazile's (2017) memoir. According to her, Debbie Wasserman Schultz had de-emphasised fundraising and, as a Clinton surrogate, had Hillary Clinton campaign headquarters direct the Democratic Party. Factoring into this was that Obama had apparently left the Democratic Party in debt, up to $\$ 24$ million. In 2015, Hillary Clinton's campaign secured the debt in exchange for oversight of the Democratic Party. The Joint Fund-Raising Agreement, Brazile (2017) says

specified that in exchange for raising money and investing in the DNC [Democratic National Committee], Hillary would control the party's finances, strategy, and all the money raised. Her campaign had the right of refusal of who would be the party communications director, and it would make final decisions on all the other staff. The DNC also was required to consult with the campaign about all other staffing, budgeting, data, analytics, and mailings.

To be clear, the agreement Brazile refers to applied to the primary process, not just the general election. Arguably, Wasserman Schultz's inattention to fundraising consolidated Clinton's control over the Democratic Party. Concurrently, the DNC had 
hired many Clinton and Obama consultants in 'make-work patronage' to prepare for the 2016 election, notwithstanding Clinton's public promise that she would rebuild "the party from the ground up". "When our state parties are strong", she added, "we win. That's what will happen" (quoted in Brazile 2017). However, the agreement between the DNC, the Hillary Victory Fund, and Hillary for America outlined how the DNC could be used as a vehicle to route funds to the Clinton campaign, skirting the $\$ 2,700$ set by the FEC as the maximum contribution to presidential campaigns (the limits for a political party's state and national committee are higher). The state parties and DNC then routed these funds, close to $\$ 350,000$ per donor, to the Hillary Victory Fund. With funds concentrated in the presidential campaign, there was little remaining to support down ballot races. Clinton surrogates effectively controlled the process. Clinton cannibalised the state parties to focus on the presidential campaign. When taking stock of the primary, Senator Elizabeth Warren said this was rigged; even the superdelegates voting for HRC show as much. In the final tally, Clinton and her supporters spent nearly $\$ 800$ million on this presidential campaign (Open Secrets $2018 \mathrm{a}$ ).

Upon publishing these revelations, Brazile was immediately scolded and scorned by Clinton surrogates in the media. These surrogates suggested that Bernie Sanders had signed a similar document. But examination of that agreement reveals one noticeable absence: any discussion about the DNC's finances or strategy. As Greenwald (2017) wrote, it had no "control provisions". While Clinton campaign staff scoffed at the suggestion of rigging (Ferguson 2017) this grandstanding was undercut by new DNC chairman Tom Perez's public statement (2017) that the 2020 primary must be "unquestionably fair and transparent" as the perception of [...] an unfair advantage undermines our ability to win". Advancing this point, Ryan Cooper (2017) argues that the practical consequences of this funding arrangement demonstrate how the Democratic Party is tied to graft and patronage, indicating that it will be very hard to achieve the fairness and transparency Perez seeks. Coopers concludes: "Right now, there is a trade-off between political success and setting up a patronage machine that caters to the top 1 percent. It's time for the party to take stances that will make it loathed by the country's economic elite". Ultimately, this funding model caters to donors, thereby dulling the impulse for the DNC to tackle the growing social inequality and disparities discussed in the previous section.

\section{Information Robber Barons and their Platforms of Power}

Another approach to mapping the civil war in the American ruling class is to examine the state of the digital news media sector. For example, 2017 was a notoriously bad year for digital news workers. Publications like Gothamist and DNA Info were closed by Joe Rickets, their billionaire owner, after the staff voted to unionise (Newman and Leland 2017), while Gawker had the year before announced bankruptcy due to litigation. Elsewhere, Sheldon Adelson bought the Las Vegas Review-Journal only to begin inserting agents to oversee the editorial slant of the paper, prompting key staff to leave (Ember 2016). Viewed from the vantage point of class struggle, these events are manoeuvres by the ruling class to curtail the power of independent media. Two big events are testament to this development. Late in the year, the media company Meredith bought Time Magazine for $\$ 2.8$ billion. Using preferred equity commitment, $\$ 650$ million of this financing comes from Koch Equity Development, a fund run by the Koch brothers. Stephen Lacy, Meredith's CEO, indicates that they want to integrate content across all "digital, television, print, video, mobile and social platforms" to consolidate 200 million American consumers, about $60 \%$ of American citizens (Rowell 2017). 
These events are not disconnected, but rather form part of a coordinated attempt to capture the means of production, circulation, and consumption of information, limiting the power of challenge. Let me explain using Gawker's closure. For several years Peter Thiel's agents sought out and funded several possible defamation cases against Gawker, eventually succeeding in 2016. A common explanation for Thiel's vengeance is that Gawker supposedly 'outed' him as gay, but this neglects that Thiel was already 'out'. Indeed, Thiel admits that his actions against Gawker are "less about revenge and more about specific deterrence" (see Sorkin 2016).

This tactic is common with Thiel. For example, Palantir, whose largest stakeholder is Thiel, planned to smear Glenn Greenwald because of his coverage (see Lipton and Savage 2011). As a self-described libertarian, and a co-founder of PayPal and investor in Linkedln, Lyft, Spotify, Reddit, Airbnb, and SpaceX, Thiel is a core figure in the digital mode of production, one who famously stated that "I no longer believe that freedom and democracy are compatible" (2009). That digital venture capitalists like Vinod Khosla, Chris Sacca, and Jessica Livingston applauded Thiel's litigation (Streitfeld and Isaac 2016) speak to how the digital elite prefer to avoid the public scrutiny of Silicon Valley, the kind of reporting that Gawker undertook.

Thiel's actions are not an anomaly. In 2012, the billionaire and major Republican donor Frank VanderSloot sued the publication Mother Jones because of their reporting on his social views. VanderSloot claimed damages of $\$ 74,999.00, \$ 1$ less than the threshold required to take the civil case to federal court, thus keeping the case in a jurisdiction where VanderSloot had influence. Mother Jones claims to have spent \$2.5 million defending this lawsuit (Jeffery and Bauerlein 2015). Elsewhere, James O'Keefe's Project Veritas provides an example of donors seeking to induce difficulties with media companies, most recently with his campaign to side-track the Washington Post's investigative reporting into Roy Moore's paedophilia. Given their status as a 501 (c)(3) non-profit, it is hard to precisely ascertain its funding; still, tax records indicate that a sizable amount of Project Veritas funding comes from the Donors Trust, a passthrough organisation financed by Charles and David Koch as well as the Bradley, Searle and DeVos families (Kotch 2017). At the level of any one particular campaign O'Keefe is mostly unsuccessful, but that is not the point of his operation. Rather, the main goal is to make it harder to conduct good journalism.

The danger Rickets, Adelson, Thiel, VanderSloot et al. pose is obvious. Any billionaire or member of the ruling class can unilaterally destroy almost any media outlet by secretly funding multiple suits regardless of merit and regardless if they lose. As litigation costs are prohibitively expensive for most media outlets, and as only in the rarest cases does the court order a losing party to pay the other side's costs, so billionaires can destroy media outlets even if the suits do not prevail. Given that most media outlets are struggling financially they are particularly vulnerable to this tactic. This is certainly a pronounced threat to freedom of expression as a political right, but also a clear tool in class struggle, whether directed below or laterally.

Lest one suspect these kinds of actions are the sole preserve of reactionaries, progressive neoliberals have also been experimenting with digital new media. Approached by Donald Graham, Jeff Bezos bought the Washington Post in 2013 for $\$ 250$ million. "I didn't know anything about the newspaper business", he admitted, "but I did know something about the Internet [...] That, combined with the financial runway that I can provide, is the reason why I bought The Post" (quoted in Isaac 2014). Under his ownership, there was restructuring, a reduction of staff, and the introduction of an app for Amazon's Kindle. More recently, Bezos has been critical of Trump's efforts to "freeze or chill the media that are examining him" (quoted in Benner and Wingfield 
2016). In a similar fashion, Pierre Omidyar, the founder of eBay, set up First Look in 2013, while Chris Hughes, an early investor in Facebook and organiser for Obama's first campaign, purchased The New Republic in 2012, seeking to use its platform and prestige to build a vertically-integrated digital media company. In Hughes's case this change of direction led to a mass exodus of staff, eventually prompting Hughes to sell the company in 2016. So while the presumption that the nexus of corporate finance, news media, and digital entrepreneurs may rehabilitate profitability in the news sector by introducing technical expertise and capital, at the moment it appears as if philanthropy remains the prevailing model for many American media companies.

The difficult of this kind of patronage is that it is conditional. For example, since 1999, Eric Schmidt, members of his family and Google have given upwards of $\$ 21$ million to the New America Foundation. Based in Washington, DC and currently employing over 200 people, the foundation is a prominent, if not the preeminent, Democratic think tank. In 2016 Schmidt became the chairperson of New America. In June of that year the New America Foundation retracted a blog post which drew critical attention to Google's European antitrust practices. The post came from the Open Markets section, whose goal was to review the market dominance of major American technology and communication companies like Google, Amazon and Facebook. Barry Lynn, who headed up Open Markets, as well as 10 other researchers in the section, were subsequently fired. Due to their work on platform monopolies, Lynn and his team had previously been warned by Anne-Marie Slaughter, the President and CEO of New America, in correspondence to them saying "We are in the process of trying to expand our relationship with Google on some absolutely key points [...] just THINK about how you are imperiling [sic] funding for others" (New America 2017).

Whereas conservative media entities like Fox News or Breitbart News tend to be unapologetic about their political agendas, platforms like Google and Facebook deploy a rhetoric which positions them as media infrastructure companies, rather than as media content companies. Part of this positioning is to avoid the responsibility for, and thus regulation of, the content circulated and consumed on their platforms. This rhetoric is enabled by lobbying. For example, halfway through 2017, Google's donor footprint was nearly $\$ 10$ million on direct lobbying while also disclosing that it funds 170 non-profit groups, many of which are orientated towards public policy (see Vogel 2017). Similarly, Facebook is also politically active. To complement corporate lobbying efforts in Washington, in September 2011 Facebook formed a PAC to channel election donations. Then in 2013 Mark Zuckerberg created Fwd.Us, a 501(c)(4) organisation that co-operates with Republicans and Democrats to ensure an open labour market for Silicon Valley (Sengupta and Lipton 2013). This is ironic given Zuckerberg's and Facebook's inattention to the rights of its users and the content on its platform. Put simply, Facebook's revenue model depends on extensive commodification facilitated by intrusive surveillance practices of unpaid labour. As per Nicole Cohen: "Extensive commodification refers to the way in which market forces shape and re-shape life, entering spaces previously untouched, or mildly touched, by capitalist social relations" (2008, 7-8). Cohen continues:

Not only is surveillance the method by which Facebook aggregates user information for third-party use and specifically targets demographics for marketing purposes, but surveillance is the main strategy by which the company retains members and keeps them returning to the site $(2008,8)$. 
This surveillance is fundamentally predicated upon the free labour of the user. As one of the mainstays of digital society, the consent by consumers to engage in the creation of the value of Facebook comes from this digital data work, which has become an increasingly lucrative commodity to extract from a person's everyday labour. Yet, as Facebook is so entrenched in the fabric of everyday life, it is uncommon to find critiques of its commodification practices. ${ }^{5}$

The late 2017 repeal of Net Neutrality principles means that media conglomerations can grant themselves concessions on public infrastructure, effectively ending a free and open Internet for most ordinary users. This privatisation also limits competitors by allowing infrastructure companies to toll packet routing based upon point of origin, destination, type of data transmitted, or protocol employed (checking these criteria requires deep packet inspection, essentially intense traffic surveillance that permit telecommunication companies to read, filter, censor, or alter content.) This practice encodes the American ruling class as the information robber barons of the $21 \mathrm{st}$ century.

Together these processes - litigation and patronage, naturalisation and ordinariness - aid the supremacy of digital platforms. They also create conditions where citizens are interpolated as consenting users, in turn becoming tokens to be fought with and over by the various blocs, whether they be directed by Thiel or Zuckerberg, each seeking to gain hegemony. And so, by using their capital and control of platforms, the 'new digital men of power' can support or hinder the consumption of content of digital news outlets; in effect, controlling the means of mental production. Granted, these ruling ideas are not shared uniformly across Silicon Valley. Thiel and Zuckerberg are emblematic of conservative and progressive neo-liberal positions locked in competition, but without an apparent decisive advantage over the other.

\section{Forging an Infrastructure for Reactionary Populism}

As Thomas Piketty (2014) has argued, rents return more than growth. This is one explanation why Charles and David Koch's combined fortune grew from $\$ 28$ billion in 2009 to nearly $\$ 100$ billion in 2017 . Well-known donors in Obama's first term (see Mayer's definitive study, 2016), of late they have been joined by the Mercer family as emblematic symbols of plutocratic wealth. Robert Mercer made his fortune in hedge fund management. As one of the main protagonists behind financialisation, he used his skills as a computer programmer to apply trading algorithms to high-volume, highfrequency trading at Renaissance Technologies. He became co-CEO of RenTech in 2010, which coincided with an Internal Revenue Service crackdown on financial abuses that caused the 2008 recession: in the case of RenTech, because of their use of 'basket options' to evade tax. As of 2017 , the IRS is seeking near $\$ 7$ billion in back taxes from RenTech. Although it is not clear if this event precipitated his political donations, at roughly the same time Mercer redirected the Mercer Family Foundation from medical non-profits to conservative political investments.

Using the 2010 Citizens United ruling, which lifted limits on corporate and non-profit organisation spending during elections, this event precipitated the move from

\footnotetext{
${ }^{5}$ There is precedent for this kind of naturalisation. As Marx wrote, "the advance of the capitalist mode of production develops a working class, which by education, tradition, habit, looks upon the conditions of that mode of production as self-evident laws of Nature [...] The dull compulsion of economic relations completes the subjection of the labourer to the capitalist. Direct force, outside economic conditions, is of course still used, but only exceptionally" $(1977,899)$.
} 
participation in widespread party membership to the $0.001 \%$, the mega donors. The Citizen's United era more easily permits members of the ruling class to alter politics and public policy, often without any public awareness. As a member of the Council for National Policy, for nearly a decade the Mercer Foundation funded right-wing infrastructure. Known highlights of this funding spree include giving the Citizens United Foundation $\$ 3.8$ million between 2011 and 2015. In roughly the same period they gave $\$ 11$ million to the Media Research Center (2017), whose aim is to "neutralize the propaganda arm of the Left: the national news media". These funds allowed a variety of political operations: a truncated list at the national level includes anti-Obama messaging campaigns and the targeting of key federal agencies like the Securities and Exchange Commission or the Department of Justice. During election cycles, they funded far-right rivals to more moderate Republican members of Congress like John McCain. The Foundation single-handedly created the 'Ground Zero Mosque' media event. And lastly, as I will elaborate upon below, the Mercers funded the freedom of information requests that drove the Clinton email scandal.

Following the Citizens United ruling, the Kochs championed a strategy where donors would pool funds to amplify political operatives for the 2012 presidential election. As per Mayer's research, the Mercers contributed \$25 million to this project. Soundly disappointed by Obama's landslide victory, Rebekah Mercer spearheaded a re-orientation towards a data-centric approach that optimised social media platforms to drive broadcast media narratives. Key to this development was the Club for Growth, where the Mercers met Andrew Breitbart in 2011. They were persuaded by his vision of instigating a culture war through digital media and, following the advice of Steve Bannon, invested $\$ 10$ million into Breitbart News. These funds convert Breitbart from a collection of blogs into a fully-functioning media organisation, a supposed counterweight to Arianna Huffington's Huffington Post. Andrew Breitbart died during this professionalisation, leaving Bannon as executive chairman to oversee a growing flock of writers like Milo Yiannopoulos and Ben Shapiro hired to create viral content. Breitbart produced the most shared political content on Facebook, giving donors considerable reach to promote anti-establishment politicians and political insurgents that sought to disrupt or capture the Republican Party. Perhaps the most notable victory was David Brat's unseating of Eric Cantor. If you will, the Mercers provided the funds that enabled the rise of fascism in the United States.

Learning from the media ecology of Breitbart's experience on Facebook, the data front was the next avenue to explore. "Mercer", Mayer (2017) writes, "having revolutionized the use of data on Wall Street, was eager to accomplish the same feat in the political realm". The Mercers self-financed a big data project to conduct online nudges. Robert Mercer invested $\$ 5$ million in Cambridge Analytica - Bannon is a former senior executive - a data mining and analysis company that created electronic dossiers with several thousand variables on 220 million Americans, using these dossiers to try to modify US citizens' behaviours and votes. Initially supporting Ted Cruz in the 2015 Republican Primary (with an $\$ 11$ million donation to a PAC run by Kellyanne Conway), the Mercers pivoted to Trump as his momentum built. It is in this window that the Mercers intervened in the campaign, often directly by posting Steven Bannon as the campaign CEO. After Trump's electoral victory, Rebekah Mercer was involved in Trump's transition team, advocating for Michael Flynn to become the national-security adviser. Other Mercer operatives like Bannon and Conway also took up important positions in the Trump Administration. Effectively, Robert Mercer bought influence that upends representative democracy. As Steve Bannon has said, "The Mercers laid the groundwork for the Trump revolution. Irrefutably, when you look at 
donors during the past four years, they have had the single biggest impact of anybody, including the Kochs" (quoted in Mayer 2017). In their war of position, they used digital media to forge an infrastructure for reactionary populism. By assembling audience power and platform analytics, the Mercers used their media enterprises to target progressive neoliberals or more moderate conservatives, causing unexpected electoral upsets. The Cambridge Analytica scandal, with Robert Mercer and Peter Thiel as central characters, is a good demonstration that capital is destabilising precisely because it allows plutocrats to interfere in international politics without much, if any, oversight.

\section{Caesarian Courts}

One explanation for the intense media operations discussed in the previous sections is because the US is not a lawless country. Rather, neo-liberalism requires the rule of law to justify and legitimate its intense concentration of power. Moreover, to employ some Gramscian descriptors, it is the law that will permit a Caesarian passive revolution to consolidate hegemony. Let me elaborate: in the US, "the federal courts have become a critical policymaking institution", Keith Whittington (2017) writes, "and as a result both parties have been pushed to treat judicial appointments as an important political battleground". Courts are not outside of politics; they offer an opportunity to "reshape the political landscape", but, if anything, Whittington says, they are a "lagging indicator of political success". In this light, the last half-century has seen political stalemate as each party was unable to decisively win the courts, at least relative to Republican reorganisation during Reconstruction, or Democratic reorganisation during the New Deal. Minimal success and partisan rotation has resulted in relative gridlock at the Supreme Court. This limbo has meant that federal circuit court appointments have increasingly become targets for Senate politics, often taking the form of obstructionism to slow the pace of confirmation, for example with Bill Clinton's Administration after the 1994 mid-term election, or in George W. Bush's first term. Growing ideological distance has exacerbated the gridlock on judicial appointments, making collecting 60 votes increasingly difficult. Moreover, it appears that judicial spoiling does not cost electoral votes, so there are few disincentives to continuing this practice. For these reasons, substantive judicial appointments effectively require a party to control the Presidency, the Senate, and the House. When those circumstances do not exist, vacancies can accumulate, sometimes for years.

When Justice Antonin Scalia died unexpectedly in early 2016, Republicans were faced with the prospect of a third Obama Supreme Court appointee, as well as Hillary Clinton's impending campaign, which if successful could perhaps fill the seats currently occupied by Ruth Bader Ginsberg and Anthony Kennedy, the oldest members of the court, thus decisively swaying the court system to progressive neoliberals. Granted, the Republican National Committee did not know who would emerge from their presidential primary process, but stalling the Obama Administration was the best option, given that they did not want the balance of the court to change. The Judicial Crisis Network, a Washington, DC-based conservative non-profit, received $\$ 17.9$ million from a single unknown donor. Drawing upon this fund, the Judicial Crisis Network and launched a $\$ 7$ million campaign to stall Merrick Garland's confirmation hearing (Sessa-Hawkins and Perez 2017). After Trump's 2016 presidential victory, the organisation subsequently spent $\$ 10$ million on advertising to support Neil Gorsuch's Supreme Court seat (Judicial Crisis Network 2017). As a 501(c)(4) legal entity, the organisation does not have to publicly disclose its donors; however, previously the 
network has received funding from the Wellspring Committee, a known dark money organisation.

Gorsuch's appointment maintained the status quo, but it did permit Trump to move the balance of power if Ginsberg's or Kennedy's seat become vacant during his presidency. In June 2018, Kennedy decided that he would move to 'senior status', effectively retiring from the US Supreme Court. The subsequent nomination of Brett Kavanaugh by the Trump Administration was surrounded by questions about Kavanaugh's legal opinions about the expansion of executive power (Kirby 2018). Other concerns about perjury were also voiced, although with good reason only really when allegations of sexual assault by Kavanaugh as a high school and university student mounted was there sustained public inquiry about his suitability for the court. Reminiscent of the speech act of "fake news", (ex. Farkas and Schou 2018) Kavanaugh declared on Fox News that "I'm not going to let false accusations drive us out of this process". His defiance mirrors that of the Republican Party, who were urgently trying to confirm his appointment prior to the 2018 midterm elections where Republicans risk losing their congressional majority (see Table 1 for a breakdown of political advertising on this issue). Following Professor Christine Blasey Ford's credible testimony to the Senate Judiciary Committee about Kavanaugh's actions, Senator Jeff Flake endorsed forwarding Kavanugh's nomination provided there was a limited investigation from the FBI. These events crown a career in which, according to Tara Golshan (2018), "Kavanaugh's truthfulness has repeatedly come into question". It is for this reason that, by 4 October 2018, more than 2,400 Law Professors declared that "he [Kavanaugh] did not display the impartiality and judicial temperament requisite to sit on the highest court of our land" (Aaronson et al. 2018). The statement follows sustained protests by Yale law students against Kavanaugh, who graduated from the university in 1990. Despite the sexual assault allegations, in early October 2018, Kavanaugh was appointed to the Supreme Court.

Of late it has been fashionable for pundits to lament that the Supreme Court has become more polarised and politicised, thus reflecting the asymmetrical ideological polarisation that has occurred in the US more broadly, and in the media more specifically (see Prior 2013 for a review of pertinent literature on the latter topic). Sadly, the notion that the Court was (and remains) above the political fray is a remnant of Cold War ideological dogma and propaganda where the Court was said to be emblematic of democratic reason and hence gave legitimacy to the American system of government. But this is not the case, for it is trivial to point out that the Supreme Court has typically been partisan, often arresting rights with each court in the post-war era tending - apart from the Warren Court - to be ever more conservative that the one preceding it. The 2018 term arguably demonstrate that the court is a de-democratizing force in the US. Key rulings like Janus v. AFSCME, National Institute of Family and Life Advocates v. Becerra, and Husted v. Randolph Institute underscore that the court consistently permits social inequities to greatly shape the lives of the vulnerable for the worse. ${ }^{6}$

${ }^{6}$ Details about the individual rulings can be found at Cornell Lar School's Legal Information Centre, https://www.law.cornell.edu/. In summary, Janus v. AFSCME SCOTUS ruled that government works who do not join unions do not need to pay for collective bargaining. The consequence is that government unions will lose a considerable source of their income, thereby reducing their ability to resist authoritarian workplaces. The ruling for National Institute of Family and Life Advocates v. Becerra concerns free speech rights trumping abortion rights insofar that religious crisis pregnancy centres in California do not need to 


\begin{tabular}{|c|c|c|}
\hline Sponsor & Estimated Spending & Market Breakdown \\
\hline Judicial Crisis Network & $\$ 3,692,730$ & $\begin{array}{l}\text { National Cable: } \$ 1,557,000 \\
\text { North Dakota: } \$ 739,970 \\
\text { Indiana: } \$ 567,210 \\
\text { West Virginia: } \$ 458,410 \\
\text { Alabama: } \$ 262,460 \\
\text { Washington, D.C.: } \$ 107,680\end{array}$ \\
\hline $\begin{array}{l}\text { National Rifle } \\
\text { Association/NRA Institute } \\
\text { for Legislative Action }\end{array}$ & $\$ 1,243,070$ & $\begin{array}{l}\text { National Cable: } \$ 144,930 \\
\text { West Virginia: } \$ 281,580 \\
\text { Indiana: } \$ 198,980 \\
\text { North Dakota: } \$ 221,000 \\
\text { Alaska: } \$ 90,840 \\
\text { Montana: } \$ 305,740\end{array}$ \\
\hline $\begin{array}{l}\text { America First Policies, } \\
\text { Inc. }\end{array}$ & $\$ 1,109,950$ & $\begin{array}{l}\text { Indiana: } \$ 477,420 \\
\text { North Dakota: } \$ 372,260 \\
\text { West Virginia: } \$ 240,730 \\
\text { National Cable: } \$ 19,540\end{array}$ \\
\hline $\begin{array}{l}\text { State Government } \\
\text { Leadership Foundation }\end{array}$ & $\$ 473,230$ & Maine: $\$ 473,230$ \\
\hline One Nation & $\$ 404,440$ & Maine: $\$ 404,440$ \\
\hline 45Committee & $\$ 118,490$ & $\begin{array}{l}\text { National Cable: } \$ 73,070 \\
\text { Washington, D.C.: } \$ 45,420\end{array}$ \\
\hline Citizens United & $\$ 27,490$ & National Cable: $\$ 27,490$ \\
\hline $\begin{array}{l}\text { Great America PAC/Great } \\
\text { America Alliance }\end{array}$ & $\$ 5,550$ & National Cable: $\$ 5,550$ \\
\hline
\end{tabular}

Table 1: Total TV spending in support of Brett Kavanaugh's confirmation hearing. This figure of $\$ 7,074,950$ spent between July until 2 October 2018 can be contrasted to the $\$ 2,470,970$ spent in opposition during the same period. Financial figures drawn from NYU School of Law's Brennan Center for Justice (2018).

By contrast, progressive neoliberals tend to put faith in the courts and constitution. For example, in February 2017 when Judge James Robart issued a nationally binding temporary restraining order on the Trump Administration's Muslim travel ban, Trump's subsequent tweets castigated the separation of powers, undermined judicial authority and pitted unreasonable security concerns against the rule of law. These reactions at judicial blocks has watered one predominant lay view that Trump's Administration will be restrained by the American constitution, the judiciary, and other state apparatuses like the $\mathrm{FBI}$ - effectively that these institutions will limit reactionary populism. I think this view is misguided. Consider that as of mid-July 2017, Trump had appointed 27 lower court judges (three times more than Obama) and 9 judges to Courts of Appeal. On average, these judges are younger than Obama's appointees, meaning that they

provide information about abortions. Finally, Husted v. Randolph Institute concerns voter engagement and participation, with the Court ruling that the state of Ohio can remove voters from the voters list. 
will, as Ronald Klain (2017) argues, decide "the scope of our civil liberties and the shape of civil rights laws in the year 2050 - and beyond". These judicial appointments will ensure that Trump's legacy will prevail. Far from limiting the Trump Administration, the courts and the constitution will be a crucial source of Caesarism's long-term power and effects. If anything, they reveal how plutocratic factions in the American ruling class have an opportunity to implement a passive revolution.

Meanwhile, notwithstanding the Gorsuch and Kavanaugh appointments, Republican donors are frustrated at stalled Trump agenda, given his Administration's flat-footed nature for the majority of 2017. "Donors are furious", Senator Cory Gardner said in September 2017. "We haven't kept our promise" (quoted in Hulse 2017). Donor dissatisfaction meant that, by October 2017, funds to the Republican National Committee were less than half that of the January 2017 fundraising tally. Russ Choma (2017) reports that in late November, days before the US Senate Tax Reform vote, Republican donors were increasingly frustrated that the Republican Party had not made gains, given that they controlled Presidency, House, and Senate. Speaking openly about this, Senator Lindsey Graham simply stated that if this course of action was not taken, "the financial contributions will stop" (quoted in Thompson 2017). Drawing tight the proverbial purse strings, donors are likely seeking to galvanise Republicans politicians into action prior to the 2018 mid-terms, where because of Trump's poor polling they might lose the 'trifecta'. In the meantime, these plutocrats have pushed the Tax Cuts and Jobs Act of 2017. This law permitted the widespread looting of the US state, allowing the ruling class to appropriate an estimated $\$ 1.5$ trillion over the coming decade. The consequences of this action are well understood: it will increase the ruling class's ability and opportunity to use the market to structure relationships with workers, meaning rentiers have more power to extract wealth. Nevertheless, the question is: which faction among the ruling class will receive the bulk of this appropriation and which political trajectory will they set?

\section{Conclusion}

Let me pull together the lines of my argument so as to contra-distinguish it from Lind's analysis. I began by examining the class struggle 'from above', suggesting that, while under stress, in the current conjecture the ruling class maintains control of the commanding heights of civil society. It is a quest to direct class war 'from above' and thereby receive the benefits that accrue from holding that position of leadership. Then I examined how factions within the ruling class use digital media companies to promote their agenda to gain dominance over the American cultural superstructure. This struggle has resulted in 'lateral' class struggle. Still, there is a stalemate between these major factions as neither entity can gain a decisive edge over the others. The courts, as a lagging indicator, reveal this longstanding 'catastrophic equilibrium'. I propose that these developments can be understood as an "organic crisis" (Gramsci 2000), one which has permitted Caesarism to arise. This is the state of America today.

American Caesarism has begun by castigating the separation of powers, undermining judicial authority and pitting unreasonable security concerns against the rule of law. Nevertheless, I have suggested that in the end, it is these same courts that will codify Caesarism into American jurisprudence, meaning that the template for Caesarism politics remain, even if any one particular ruler exits the scene. As such, the civil war I have described concerns the quest for hegemony under conditions of extreme social inequality. Granted, "every epoch is characterized by complex historical upheavals", Gramsci wrote, but this should not permit "indifferentism" nor "induce a belief in some kind of fatalism" $(2000,263-264)$. To this end, I think there is much heart 
to be taken from resurgent broad-based socialist politics in the United States - when democratisation does come, it will emerge from this politics.

\section{References}

Aaronson, Mark, Richard Abel, David Abraham, Susan Abraham, Kathryn Abrams, Jamie Abrams, Alice Abreu et al. 2018. The Senate Should Not Confirm Kavanaugh. The New York Times, October 4. Accessed October 7, 2018. https://www.nytimes.com/interactive/2018/10/03/opinion/kavanaugh-law-professorsletter.html

Alberta, Tim. 2017. John Boehner Unchained. Politico Magazine, November/December. Accessed September 15, 2018. https://www.politico.com/magazine/story/2017/10/29/johnboehner-trump-house-republican-party-retirement-profile-feature-215741

Albrecht, Michael Mario. 2017. Bernie Bros and the gender schism in the 2016 US presidential election. Feminist Media Studies 17 (3): 509-513.

Anderson, Perry. 1976. The Antinomies of Antonia Gramsci. New Left Review 100: n.p.

Arsenault, Amelia and Manual Castells. 2008. Switching Power: Rupert Murdoch and the Global Business of Media Politics: A Sociological Analysis. International Sociology 23 (4): 488-513.

Baker, Peter. 2017. Both Bush Presidents Worry Trump Is Blowing Up the G.O.P. The New York Times, November 4. Accessed November 4, 2017. https://www.nytimes.com/2017/11/04/us/politics/bush-president-book-trump.html? $\quad \mathrm{r}=0$

Beeton, Dan and Ming Chun Tang. 2016. U.S.-Latin American Relations are at an All-Time Low. The Hill. May 26. Accessed October 24, 2018. https://thehill.com/blogs/congressblog/foreign-policy/281277-us-latin-american-relations-are-at-an-all-time-low

Benner, Katie and Nick Wingfield. 2016. Jeff Bezos, Riding High, Defends Decision to Buy Washington Post. The New York Times, June 1. Accessed October 15, 2018.

https://www.nytimes.com/2016/06/01/technology/jeff-bezos-riding-high-defends-decisionto-buy-washington-post.html

Brazile, Donna. 2017. Inside Hillary Clinton's secret takeover of the Democratic National Committee. Politico, November 3. Accessed November 3, 2017. https://www.politico.eu/article/inside-hillary-clintons-secret-takeover-of-the-dnc/

Briziarelli, Marco and Susana Martinez Guillem. 2016. Reviving Gramsci. New York: Routledge.

Choma, Russ. 2017. Republican Donors Are Mad as Hell and Closing Their Checkbooks. Mother Jones, November 30. Accessed November 30, 2017.

http://www.motherjones.com/politics/2017/11/republican-donors-are-mad-as-hell-andclosing-their-checkbooks/

Clinton, Hillary Rodham. 2014. Hillary Clinton reviews Henry Kissinger's 'World Order', Washington Post. September 4. Accessed October 24, 2018.

https://www.washingtonpost.com/opinions/hillary-clinton-reviews-henry-kissingers-worldorder/2014/09/04/b280c654-31ea-11e4-8f02-03c644b2d7d0 story.html

Cohen, Marty, David Karol, Hans Noel, and John Zaller. 2008. The Party Decides:

Presidential Nominations Before and After Reform, Chicago: University of Chicago Press

Cohen, Nicole. 2008. The Valorization of Surveillance: Towards a Political Economy of Facebook. Democratic Communiqué 22 (1): 5-22. http://journals.fcla.edu/demcom/article/view/76495/74124

Cooper, Ryan. 2017. This is the real scandal in the Democratic Party. The Week, November 8. Accessed November 8, 2017. http://theweek.com/articles/735837/real-scandaldemocratic-party

Correct the Record. 2016. Barrier Breakers 2016: A Project Of Correct The Record [Press Release]. Accessed October 27, 2018. https://www.politico.com/f/?id=00000154-3082d20b-a1fc-b3e3368b0000 
Couldry, Nick and Andreas Hepp. 2016. The Mediated Construction of Reality. Cambridge: Polity.

Ember, Sydney. 2016. In Sheldon Adelson's Newsroom, Looser Purse Strings and a Tighter Leash. The New York Times, May 22. Accessed May 22, 2016.

https://www.nytimes.com/2016/05/23/business/media/in-adelsons-newsroom-looserpurse-strings-and-a-tighter-leash.html

Farkas, Johan and Jannick Schou. 2018. Fake News as a Floating Signifier: Hegemony, Antagonism and the Politics of Falsehood. Javnost - The Public 25 (3): 298-314.

Ferguson, Jesse. 2017. Open Letter from Hillary for America 2016 Team. Medium, November 4. Accessed November 4, 2017. https://medium.com/@jesse 41795/openletter-from-hillary-for-america-2016-team-f1c545304be1

Filipovic, Jill. 2017. Hillary Clinton is right about Bernie Sanders. CNN Opinion, September 6. Accessed September 4, 2018. https://edition.cnn.com/2017/09/05/opinions/hillary-clintonbook-bernie-sanders-filipovic/index.html

Fuchs, Christian and Dwyane Winseck. 2011.Critical Media and Communication Studies Today. A Conversation. tripleC: Communication, Capitalism \& Critique 9 (2): 247-271.

Fuchs, Christian. 2009. Some Theoretical Foundations of Critical Media Studies: Reflections on Karl Marx and the Media. International Journal of Communication 3: 369-402.

Goldman, Adam and Alan Rappeport. 2016. Emails in Anthony Weiner Inquiry Jolt Hillary Clinton's Campaign. The New York Times, October 28. Accessed October 28, 2016. https://www.nytimes.com/2016/10/29/us/politics/fbi-hillary-clinton-email.html

Golshan, Brett. 2018. Did Brett Kavanaugh perjure himself? The debate, Explained. Vox. October 2. Accessed October 24, 2018. https://www.vox.com/2018/10/2/17927606/brettkavanaugh-perjury-lied-congress

Gramsci, Antonio. 1971. Selections from the Prison Notebooks of Antonio Gramsci, edited and translated by Quintin Hoare and Geoffrey Nowell Smith. New York: International Publishers. Accessed October 10, 2018. https://archive.org/stream/AntonioGramsciSelectionsFromThePrisonNotebooks/AntonioGramsci-Selections-from-the-Prison-Notebooks djvu.txt

Greenwald, Glenn. 2017. Four Viral Claims Spread by Journalists on Twitter in the Last Week Alone That Are False. The Intercept, November 5. Accessed November 5, 2017. https://theintercept.com/2017/11/05/four-viral-claims-spread-by-journalists-on-twitter-inthe-last-week-alone-that-are-false/

Greenwald, Glenn. 2016. The "Bernie Bros" Narrative: A Cheap Campaign Tactic Masquerading as Journalism and Social Activism. The Intercept. January 31. 2016. Accessed October 24, 2018. https://theintercept.com/2016/01/31/the-bernie-brosnarrative-a-cheap-false-campaign-tactic-masquerading-as-journalism-and-social-activism/

Hepp, Andreas, Stig Hjarvard and Knut Lundby. 2015. Mediatization: Theorizing the Interplay between Media, Culture and Society, Media, Culture \& Society 37 (2): 314-324.

Hess, Amanda. 2014. Why Women Aren't Welcome on the Internet. Pacific Standard, January 6. Accessed September 4, 2018. https://psmag.com/social-justice/women-arentwelcome-internet-72170

Hoffmann-Lange, Ursula. 2007. Methods of Elite Research. In The Oxford Handbook of Political Behaviour, edited by Russell J. Dalton and Hans-Dieter Klingemann, 910-927. Oxford: Oxford University Press.

Hulse, Carl. 2017. Behind New Obamacare Repeal Vote: 'Furious' G.O.P. Donors. The New York Times, September 22. Accessed September 22, 2017. https://www.nytimes.com/2017/09/22/us/politics/republican-donors-obamacare-repeal.html Humphrys, Elizabeth. 2018. Anti-Politics, the Early Marx and Gramsci's 'Integral State'. Thesis Eleven 147 (1): 29-44.

Humphrys, Elizabeth and Ihab Shalbak. 2018. On 'Heroic Fury' and Questions of Method in Antonio Gramsci. Thesis Eleven 147 (1): 3-8. 
Isaac, Mike. 2014. Amazon's Jeff Bezos Explains Why He Bought The Washington Post. The New York Times, December 2. Accessed November 4, 2017.

https://bits.blogs.nytimes.com/2014/12/02/amazons-bezos-explains-why-he-bought-thewashington-post/

Jeffery, Clara and Monika Bauerlein. 2015. We Were Sued by a Billionaire Political Donor. We Won. Here's What Happened. Mother Jones. October 8. Accessed October 24, 2018 https://www.motherjones.com/media/2015/10/mother-jones-vandersloot-melaleucalawsuit/

Judicial Crisis Network. 2017. Judicial Crisis Network Launches $\$ 10$ Million Campaign to Preserve Justice Scalia's Legacy, Support President-Elect Trump Nominee. Press Release, January 9. https://judicialnetwork.com/judicial-crisis-network-launches-10million-campaign-preserve-justice-scalias-legacy-support-president-elect-trump-nominee/

Kirby, Jen. 2018. 7 legal experts on how Kavanaugh views executive power - and what it could mean for Mueller. Vox, July 11. Accessed September 4, 2018.

https://www.vox.com/policy-and-politics/2018/7/11/17551648/kavanaugh-mueller-trumpexecutive-power-legal

Klain, Ronald. 2017. The One Area where Trump has been Wildly Successful. The Washington Post, July 19. Accessed July 19, 2017.

https://www.washingtonpost.com/opinions/the-one-area-where-trump-has-been-wildlysuccessful/2017/07/19/56c5c7ee-6be7-11e7-b9e22056e768a7e5 story.html?utm term=.5c68dafbef8 $f$

Kotch, Alex. 2017. Who's Behind The 'Project Veritas' Sting Operation Against The Washington Post? International Business Times, November 28. Accessed November 28, 2017. http://www.ibtimes.com/political-capital/whos-behind-project-veritas-sting-operationagainst-washington-post-2620949

Lind, Michael. 2017. The New Class War. American Affairs 1(2): 19-44. Accessed 22 October, 2018. https://americanaffairsjournal.org/2017/05/new-class-war

Lipton, Eric, and Charlie Savage. 2011. Hackers Reveal Offers to Spy on Corporate Rivals. New York Times, February 11. Accessed October 242018. http://www.nytimes.com/2011/02/12/us/politics/12hackers.html

Mann, Geoff. 2016. Value and Exploitation. New Proposals: Journal of Marxism and Interdisciplinary Inquiry 9 (1): 8-14.

Marx, Karl and Friedrich Engels. 1970. The German Ideology. London: Laurence \& Wishart. Marx, Karl. 1977. Capital, Volume One. New York: Vintage.

Marx, Karl. 2006/1986. The Eighteenth Brumaire of Louis Bonaparte: Preface to the Second Edition (1869). Accessed September 4, 2018. https://www.marxists.org/archive/marx/works/1852/18th-brumaire/index.htm

Mayer, Jane. 2016. Dark Money: The Hidden History of the Billionaires Behind the Rise of the Radical Right. New York: Doubleday.

Mayer, Jane. 2017. The Reclusive Hedge-Fund Tycoon Behind the Trump Presidency. The New Yorker, March 27. Accessed March 27, 2017. https://www.newyorker.com/magazine/2017/03/27/the-reclusive-hedge-fund-tycoonbehind-the-trump-presidency

McNally, Mark and John Schwarzmantel. 2009. Gramsci and Global Politics. Milton Park: Routledge.

Media Research Center. 2017. About the MCR [webpage]. Accessed December 9, 2017. www.mrc.org/about

Meyer, Robinson. 2015. Here Comes the Berniebro. The Atlantic. October 17. Accessed October 24, 2018/ https://www.theatlantic.com/politics/archive/2015/10/here-comes-theberniebro-bernie-sanders/411070/

Meyer, Robinson. 2016. It's Not Just Berniebros. The Atlantic. February 5. Accessed October 24, 2018. https://www.theatlantic.com/politics/archive/2016/02/berniebro-revisited/460212/ 
New America. 2017. In the Interest of Transparency, New America Releases Email Correspondence with Barry Lynn. August 30, 2017. Accessed October 10, 2018. https://www.newamerica.org/new-america/press-releases/interest-transparency-newamerica-releases-email-correspondence-barry-lynn/

The New York Times. 1976. 'Welfare Queen' Becomes Issue in Reagan Campaign. February 15. Accessed October 24, 2018. https://www.nytimes.com/1976/02/15/archives/welfarequeen-becomes-issue-in-reagan-campaign-hitting-a-nerve-now.html

Newman, Andy, and John Leland. 2017. DNAinfo and Gothamist Are Shut Down After Vote to Unionize. The New York Times, November 2. Accessed November 2, 2017. https://www.nytimes.com/2017/11/02/nyregion/dnainfo-gothamist-shuttingdown.html? $r=0$

Nixon, Brice. 2017. Critical Communication Policy Research and the Attention Economy: From Digital Labor Theory to Digital Class Struggle. International Journal of Communication 11: 4719-4730.

Open Secrets. 2018a. 2016 Presidential Race [webpage]. Accessed October 8, 2018. https://www.opensecrets.org/pres16

Open Secrets. 2018b. Sen. Bernie Sanders [webpage]. Accessed 25 September 25, 2018. https://www.opensecrets.org/pres16/candidate.php?id=N00000528

Open Secrets. 2018c. Priorities USA Action [webpage]. Accessed 25 September 25, 2018. https://www.opensecrets.org/pacs/lookup2.php?cycle=2016\&strlD=C00495861.

Perez, Tom. 2017. Making 2020 Transparent. Medium, November 4. Accessed November 4, 2017. https://medium.com/@TheDemocrats/making-2020-transparent-87ebab06ab0a

Piketty, Thomas. 2014. Capital in the Twenty-First Century. Cambridge, MA: Harvard University Press.

Prior, Markus. 2013. Media and Political Polarization. Annual Review of Political Science 2013 (16): 101-127.

Rappeport, Alan. 2016. Gloria Steinem and Madeleine Albright Rebuke Young Women Backing Bernie Sanders, The New York Times. February 7. Accessed October 24, 2018. http://www.nytimes.com/2016/02/08/us/politics/gloria-steinem-madeleine-albright-hillaryclinton-bernie-sanders.html

Raskin, Sam. 2017. Nancy Pelosi to Leftist NYU Student: We're Capitalists, Deal With It. NYULocal, February 1. Accessed February 1, 2017. https://nyulocal.com/nancy-pelosi-toleftist-nyu-student-were-capitalists-deal-with-it-abf1e8e04e46

Reed Adolph and Daniel Zamora. 2016. Bernie Sanders and the New Class Politics [interview]. Jacobin, August 8. Accessed September 4, 2018.

http://www.jacobinmag.com/2016/08/bernie-sanders-black-voters-adolph-reed-trumphillary/

Rowell, Andy. 2017. Climate-Denying Koch Brothers Back Purchase of Time Magazine. EcoWatch, November 27. Accessed November 27, 2017.

https://www.ecowatch.com/climate-denying-koch-brothers-back-purchase-of-timemagazine-2512979338.html

Saez, Emmanuel and Gabriel Zucman. 2014. Wealth Inequality in The United States Since 1913: Evidence From Capitalized Income Tax Data, NBER Working Paper 20625, October.

Sanders, Bernie. 2012. United Against the War on Women. Huffington Post, April 30. Accessed September 4, 2018. https://www.huffingtonpost.com/rep-bernie-sanders/unitedagainst-the-war-on b 1464730.html

Semenova, Elana. 2018. Research Methods for Studying Elites. In The Palgrave Handbook of Political Elites, edited by Heinrich Best and John Higley, 71-77. London: Palgrave Macmillan.

Sengupta, Somini and Eric Lipton. 2013. Silicon Valley Group's Political Effort Causes Uproar. The New York Times, May 8. Accessed September 4, 2018. http://www.nytimes.com/services/xml/rss/yahoo/myyahoo/2013/05/09/technology/fwdusraises-uproar-with-advocacy-tactics.xml 
Sessa-Hawkins, Margaret and Andrew Perez. 2017. Dark Money Group Received Massive Donation In Fight Against Obama's Supreme Court Nominee. Maplight, October 24.

Accessed September 4, 2018. https://maplight.org/story/dark-money-group-receivedmassive-donation-in-fight-against-obamas-supreme-court-nominee/

Sorkin, Andrew Ross. 2016. Peter Thiel, Tech Billionaire, Reveals Secret War With Gawker. The New York Times, May 25. Accessed October 24, 2018.

https://www.nytimes.com/2016/05/26/business/dealbook/peter-thiel-tech-billionairereveals-secret-war-with-gawker.html

Stockman, Farah. 2016. On Crime Bill and the Clintons, Young Blacks Clash With Parents. The New York Times, April 18. Accessed October 24, 2018. http://www.nytimes.com/2016/04/18/us/politics/hillary-bill-clinton-crime-bill.html

Streitfeld, David and Mike Isaac. 2016. Tech Titans Raise Their Guard, Pushing Back Against News Media. The New York Times, May 27. Accessed November 17, 2017. https://www.nytimes.com/2016/05/28/business/media/tech-titans-raise-their-guardpushing-back-against-news-media.html

Sultan, Niv. 2017. Election 2016. Open Secrets, April 13. Accessed September 4, 2018. https://www.opensecrets.org/news/2017/04/election-2016-trump-fewer-donors-providedmore-of-the-cash/

The Brennan Center for Justice. 2018. Follow the Money: Tracking TV Spending on the Kavanaugh Nomination [blog post]. The Brennan Center for Justice, NYU School of Law. Accessed October 10, 2018. https://www.brennancenter.org/analysis/buying-timesupreme-court-advertisements?

Thiel, Peter. 2009. The Education of a Libertarian. Cato, April 13. Accessed November 17 2017. https://www.cato-unbound.org/2009/04/13/peter-thiel/education-libertarian

Thomas, Peter. 2009. The Gramscian Moment. Leiden: Brill.

Thompson, Derek. 2017. Why the GOP's Dream of Tax Reform Is (Probably) Doomed. The Atlantic, November 9. Accessed November 9, 2017. https://www.theatlantic.com/business/archive/2017/11/gop-tax-cut/545450/

Traister, Rebecca. 2016. Hillary Clinton vs. Herself. New York Magazine, May 30. Accessed October 24, 2018. http://nymag.com/intelligencer/2016/05/hillary-clinton-candidacy.html

Vogel, Kenneth P. and Isaac Arnsdorf. 2016. Trump's campaign dwarfed by Clinton's.

Politco. May 21. Accessed October 24, 2018.

http://www.politico.com/story/2016/05/trumps-campaign-dwarfed-by-clintons223438\#ixzz4IzcezjP5

Vogel, Kenneth. 2017. Google Critic Ousted From Think Tank Funded by the Tech Giant. The New York Times, August 30. Accessed August 30, 2017. https://www.nytimes.com/2017/08/30/us/politics/eric-schmidt-google-new-america.html?

Walsh, Joan. 2016. Bernie Sanders Is Hurting Himself by Playing the Victim. The Nation. May 19. Accessed October 1, 2018. https://www.thenation.com/article/bernie-sanders-ishurting-himself-by-playing-the-victim/

Whittington, Keith. 2017. Partisanship, Norms and Federal Judicial Appointments. Accessed November 29, 2017. https://balkin.blogspot.com/2017/11/partisanship-norms-and-federaljudicial.html

Wilz, Kelly. 2016. Bernie Bros and Woman Cards: Rhetorics of Sexism, Misogyny, and Constructed Masculinity in the 2016 Election. Women's Studies in Communication 39 (4): 357-360.

Wolff, Edward. 2014. Household Wealth Trends in the United States, 1962-2013: What Happened Over the Great Recession? NBER Working Paper No. 20733.

Wolff, Edward. 2017. A Century of Wealth in America. Cambridge, MA: Harvard University Press. 


\section{About the Author}

Scott Timcke

Scott Timcke studies the intersection of wealth and power in light of the post-war factors that have shaped them. In the coming years his research agenda will focus on how states and markets mediate human relationships. 